Acta vet. scand. $1986,27,159-171$.

From the National Veterinary Institute, Helsinki, Finland.

\title{
A SEROLOGICAL SURVEY OF ENTERIC PARVO- VIRUS INFECTIONS IN FINNISH FUR-BEARING ANIMALS
}

\author{
By \\ Pirjo Veijalainen
}

\begin{abstract}
VEIJALAINEN, PIRJO: A serological survey of enteric parvovirus infections in Finnish fur-bearing animals. Acta vet. scand. 1986, 27, 159-171. - Parvovirus infections in Finnish fur animals, i.e. ferrets, raccoon dogs, blue foxes and mink, were studied. The ferret was found to be the only insusceptible animal. Parvo enteritis of raccoon dogs, reported since 1980, has spread from East Finland to other parts of the country. A new candidate for the Parvovirus family was found to infect blue foxes. According to serologic investigations, the virus resembled feline panleukopenia virus more than canine parvovirus. Clinical signs during the infection have been mild. Annual vaccination has not eradicated mink enteritis virus on farms, but the disease has taken a subclinical form.
\end{abstract}

viralenteritis; mink; bluefox; raccoon dog; ferret.

The role played by parvoviral infections in contagious diarrhoea in cats and mink is well-known. Feline panleukopenia virus (FPV) may cause disease in most members of the family Felidae. In 1947 a virus closely related to or identical with FPV was recognized as a causative agent of enteritis on a mink farm in Ontario, Canada. Since then the disease, mink virus enteritis, has been found to occur wherever mink are farmed. The first cases in Finland wëre diagnosed in 1962 (Kangas 1962). The vaccination of kits at the age of 8 weeks has been used for controlling the diesase ever since inactivated mink enteritis vaccines became available.

Within the past few years a new disease characterized by haemorrhagic enteritis has become a major problem in dogs. A parvovirus (CPV) was isolated from diseased animals by Appel et al. (1979). The virus is closely related to FPV and mink enteritis virus (MEV), but differs in its antigenic structure (Parrish 
et al. 1982), host range and biological characteristics (Carmichael et al. 1980). Genome differences between FPV, MEV and CPV have been shown using DNA restriction enzymes (McMaster et al. 1981, Tratschin et al. 1982).

The natural host range for CPV is currently undetermined. In addition to domestic dogs, canine parvovirus infection has been reported sporadically in a few species of nondomestic carnivores: in captive manned wolves (Fletscher et al. 1979), bush dogs (Janssen et al. 1982), crab-eating foxes (Mann et al. 1980) and coyotes (Ellerman et al. 1980, Thomas et al. 1984). Severe enteritis attributed to CPV has also been diagnosed in housed raccoon dog kits (Nyctereutes procyonoides) in eastern Finland (Neuvonen et al. 1982).

Conditions clinically and histo-pathologically resembling feline panleukopenia have been reported from arctic fox (Alopex lagopus) (Phillips 1943) and porcupines (Frelier et al.1984). Attempts to isolate the causative agent were either not done or were unsuccessful.

Barker et al. (1983) described artificial inoculations of raccoons (Procyon lotor), red foxes (Vulpes vulpes), skunks (Methitis mephitis) and mink (Mustela vision) with various parvoviruses, FPV, MEV and CPV. Mink and raccoons were succeptible to MEV and FPV. Inoculation of blue foxes with FPV seemed to elevate antibody titers, but no clinical signs were seen.

It is apparent that parvoviruses can also affect species other than the original one. After the outbreak among farmed raccoon dogs in 1980, a serological survey was carried out to study the extent to which CPV had spread since the first reported cases of the disease, and to reveal possible infections in other fur animals.

Furthermore, the investigation would also indicate how well we had succeeded in eradicating mink enteritis through vaccination.

\section{Serum samples}

\section{MATERIAL AND METHODS}

During the period from November 1981 to January 1982, a total of 1324 samples of blue fox (Alopex lagopus) serum were collected from 50 farms, 942 mink sera from 20 farms, 569 raccoon dog sera from 26 farms and 442 fitch ferret sera from 10 
farms. Samples were collected randomly, no discrimination being made between age or sexual class.

During the follow-up studies in 1983 and 1984 fur farmers were asked to send material for serological examination from blue foxes and raccoon dogs in cases where they had abortion, neonatal death or enteritis problems. In 1983 reccoon dog sera from 9 farms and in 1984 from 15 farms were submitted for parvovirus antibody tests. Blue fox sera were sent from 169 farms in 1983 and from 142 farms in 1984.

\section{Haemagglutination inhibition test}

Antibody to parvoviruses was assayed using a haemagglutination inhibition test (HI) in microtiter plates as described by Carmichael et al. (1980). A CPV isolate, recovered from the faeces of an experimentally infected raccoon dog, was used as the haemagglutinin (HA) antigen. An HA titer of 8 was added for each serum dilution. A $1 \%$ suspension of porcine erythrocytes served as the indicator cells. The $\mathrm{pH}$ of the test system was 7.2. Phosphate buffered saline (PBS) was used as diluent. Prior to testing, the sera were heat inactivated at $56^{\circ} \mathrm{C}$ for 30 min and absorbed for $2 \mathrm{~h}$ at $21^{\circ} \mathrm{C}$ by adding 9 parts of porcine erythrocyte suspension ( $5 \%$ ) to 1 part of serum. In order to detect nonspecific agglutinins the first serum dilution was made in duplicate, and the antigen substituted by PBS in 1 of the 2 . Each test series included a red cell control, antigen back titration and standard reference serum controls. A titer of 160 or more was considered specific for parvovirus. Unspecific inhibitions and agglutinations were common in lower titres (Carmichael et al. 1980, Thomas et al. 1984).

\section{Indirect fluorescent antibody staining}

Indirect immunofluorescence staining of the parvovirus was used to confirm the specificity of positive $\mathrm{HI}$ reactions of blood samples.

IgG from the serum of a blue fox and a raccoon dog were precipitated using a saturated solution of ammonium sulphate (The \& Feltkamp 1970). The precipitates were dissolved in $0.0175 \mathrm{~mol} / \mathrm{l}$ phosphate buffer $\mathrm{pH} 7.2$, and dialyzed against the same buffer. The IgGs were further purified in a Sephacel (Pharmacia Fine Chemicals) column according to the method 
of Jaton et al. (1979). Phosphate buffer, as described above, was used as the eluent. The first protein fraction contained IgG. Antisera against raccoon dog and blue fox immunoglobulins were raised in rabbits; $100 \mu \mathrm{g}$ of protein in $0.5 \mathrm{ml}$ of PBS was combined with the same amount of Freund's incomplete adjuvant. The rabbits were injected subcutaneously 3 times at 2 week intervals. Ten days after the final booster the animals were bled and the sera collected for further use.

Raccoon dog parvovirus was propagated in a canine epithelial cell line (KP, originating from the National Veterinary Institute, Helsinki). Appropriate anount of cells $(1 \mathrm{ml})$ and $0.1 \mathrm{ml}$ of parvovirus containing cell culture fluid were seeded at the same time in small tubes with a coverslip on the bottom. The virus was allowed to replicate for $48 \mathrm{~h}$ and the coverslips then rinsed quickly in aqua and fixed in acetone for 5 min.

In the indirect fluorescent staining method the sera from raccoon dogs and blue foxes were diluted 1 to 10 in PBS. A drop of each dilution was added to the fixed cell monolayers, incubated in a humified chamber at $37^{\circ} \mathrm{C}$ for $30 \mathrm{~min}$ and washed for 10 min in PBS. Excess moisture was allowed to evaporate and unconjugated rabbit anti-raccoon dog IgG or anti-blue fox IgG were spread on the coverslips in dilutions of 1 to 10 . The incubation and washing procedure was repeated. Fluorescein-conjugated anti-rabbit IgG (Dakopatts) in dilutions of 1 to 20 was added to the cells. The incubation time was the same as above. Finally the coverslips were rinsed and mounted in a drop of glycerolPBS pH 7.2 and examined under an UV microscope.

\section{Competitive serological enzyme-linked immunosorbent assay (ELISA)}

Competitive serological ELISA is more specific and able to detect smaller amounts of antibodies than the HI-test. It was used to confirm positive and negative reactions in some borderline ferret samples.

The HI-test also failed to detect post-vaccination antibodies in mink. Approximately 20 sera from 13 farms were studied with the more sensitive ELISA method to determine the serological situation after vaccination.

Raccoon dog parvovirus was purified from faecal samples. Suspensions $(20 \%)$ were treated with chloroform (1 part to 10 parts of suspension) overnight at $4{ }^{\circ} \mathrm{C}$ on a magnetic stirrer. 
The mixture was clarified by centrifuging for $15 \mathrm{~min}\left(4^{\circ} \mathrm{C}\right)$, at $10000 \mathrm{rpm}$ with a Sorval rotor SS 34. The virus in the supernatant fluid was sedimented by centrifuging at $100000 \mathrm{~g}$ for $3 \mathrm{~h}$ with a Beckman ultracentrifuge. The pellet was suspended in $0.5 \mathrm{ml}$ of TE buffer $(0.01 \mathrm{~mol} / \mathrm{l}$ Tris-HCl, $\mathrm{pH} 7.4,0.1 \mathrm{~mol} / \mathrm{l}$ $\mathrm{NaCl}, 0.001 \mathrm{~mol} / \mathrm{l}$ ED'TA) and further purified by banding in a sucrose gradient at $45000 \mathrm{rpm}$ for $40 \mathrm{~min}$ using a Beckman SW 50 rotor. Sucrose gradients were formed by pipetting $4.5 \mathrm{ml}$ of $17.5 \%$ sucrose in TE buffer into centrifuge tubes. The tubes were frozen at $-20^{\circ} \mathrm{C}$ and slowly thawed at refrigerator temperature overnight. When thawed they were ready for use (Lei 1978). Virus-containing farctions were detected using the HA test, pooled and centrifuged in a $\mathrm{CsCl}$ gradient. The gradient was formed as above by freezing $2 \mathrm{ml}$ of $55 \% \mathrm{CsCl}$ in TE buffer at $-70^{\circ} \mathrm{C}$ and thawing at $4^{\circ} \mathrm{C}$. The peak fractions were dialyzed against PBS or pelleted using a Beckman Ti 50 rotor at 35000 rpm for $3 \mathrm{~h}$ at $4^{\circ} \mathrm{C}$.

Purified raccoon dog parvovirus was used for immunizing rabbits. The protein concentration of the virus preparates was measured. For each inocula $30 \mu \mathrm{g}$ of virus protein in $0.5 \mathrm{ml}$ of PBS was mixed with an equal amount of Freund's incomplete adjuvant. A subcutaneous injection and 2 or 3 boosters at twoweek intervals were given before the final bleeding.

In the ELISA test rabbit anti-parvo antibodies were used for catching antibody in microtiter wells and for an anti-parvo horse-radish labeled conjugate. After ammonium sulphate precipitation and Sephacel chromatography of the antibodies (Jaton 1979), the conjugaion with horse-radish was made as described by Wilson \& Nakane (1978).

Irradiated, 96-well microtiter plates (Dakopatts) were coated with rabbit anti-parvovirus antibodies $\left(0.1 \mathrm{ml}\right.$ per well) as $10^{-3}$ or $10^{-4}$ dilutions in carbonate-bicarbonate buffer $(0.05 \mathrm{~mol} / \mathrm{l}$, pH 9.6, Grauballe et al. 1981). Adsorption was allowed to proceeded for $1 \mathrm{~h}$ at room temperature and then the plates were washed for 5 min by filling the wells with PBS containing $0.05 \%$ of tween $\mathrm{R}$ (20). Washing was repeated 3 times. A cell culture medium of raccoon dog parvovirus was diluted 1 to 10 in PBStween plus $0.5 \%$ of bovine serum albumin (BSA) and used as the antigen. The antigen dilution was added to each well $(0.1 \mathrm{ml})$ and incubated at $4^{\circ} \mathrm{C}$ overnight. Afer he rinsing step ( 3 times $5 \mathrm{~min}$ ), $0.05 \mathrm{ml}$ of the serum to be tested or the control serum 
In dilution 1:100 in PBS-tween-BSA were added to 2 wells, and $0.05 \mathrm{ml}$ of anti-parvo horse-radish conjugate in appropriate dilution was then pipetted into the same wells. The plate was kept for $1 \mathrm{~h}$ at room temperature. After 3-fold rinsing, freshly prepared substrate (orthophenylenediamine $0.4 \mathrm{mg} / \mathrm{ml}+0.0006 \%$ $\mathrm{H}_{2} \mathrm{O}_{2}$ in $0.1 \mathrm{~mol} / 1$ citrate buffer $\left.\mathrm{pH} \mathrm{5.0}\right)$ was used $(0.1 \mathrm{ml} /$ well $)$ to develope the colour. The reaction was stopped after $30 \mathrm{~min}$ incubation at room temperature by adding $0.15 \mathrm{ml}$ of $2 \mathrm{~mol} / \mathrm{l}$ sulphuric acid per well and the adsorbance measured at $492 \mathrm{~nm}$. Negative and positive reference sera pretested by the HI technique, and a control in which serum dilution was substituted by buffer were included in each test procedure. The O.D. values of the test sera were compared to those obtained with negative and positive controls.

\section{RESULTS}

The antibodies found in housed raccoon dogs, blue foxes, mink and ferrets are summarized in Table 1.

T a ble 1. The results of the HI tests in $1981-82,1983$ and 1984 .

\begin{tabular}{|c|c|c|c|c|}
\hline & \multicolumn{2}{|c|}{ No. of animals } & \multicolumn{2}{|c|}{ No. of farms } \\
\hline & tested & positive & tested & positive \\
\hline \multicolumn{5}{|l|}{$1981-82$} \\
\hline Ferrets & 442 & 0 & 10 & 0 \\
\hline Raccoon dogs & 569 & 245 & 26 & 12 \\
\hline Blue foxes & 1324 & 279 & 50 & 13 \\
\hline Mink & 942 & 26 & 20 & 5 \\
\hline \multicolumn{5}{|l|}{1983} \\
\hline Blue foxes & - & - & 169 & 59 \\
\hline Raccoon dogs & - & - & 9 & 5 \\
\hline \multicolumn{5}{|l|}{1984} \\
\hline Blue foxes & - & - & 142 & 54 \\
\hline Raccoon dogs & - & - & 15 & 7 \\
\hline
\end{tabular}

Fitch ferrets

Ferrets do not seem to be naturally susceptible to enteric parvoviruses. All 422 samples tested were negative. The HI-test suggested a weak positive reaction in 8 samples, but further investigation with the ELISA test showed that the titres of $80-$ 160 were unspecific. 


\section{Raccoon dogs}

A large proportion of the raccoon dog sera showed positive titres to parvovirus. In 1981-82 almost half of the farms (12 out of 26 ) and animals (245 out of 569) had suffered from the diesase. All positive reactors came from eastern Finland. During 1983, 5 farms out of a total of 9 were infected. Enteritis had spread to southern parts of the country. In 1984, 15 farms were examined and 7 of them were found to have raccoon dogs with high antibody titres. The disease continued to spread, this time to southwestern and western Finland.

\section{Blue foxes}

Blue foxes on 13 farms in the western part of the country reacted positively when tested by the $\mathrm{HI}$ method. The farms were situated close to each other in 3 neighbouring districts. Out of 1324 foxes examined, 279 had positive titres ranging from 160 to 2560 .

An indirect immunofluorescence test was carried out with parvovirus infected cell cultures and 10 highly parvo-positive blue fox sera in order to confirm that the reactions found with the HI were specific. Sera from raccoon dogs with antiparvo antibody titres served as positive controls. Samples from each animal species stained cultures identically. Strong nuclear fluorescence was present in the majority of the fixed cells.

Since no blue fox parvovirus isolate was available, the relationship between the putative virus and known ones was determined serologically using parallel $\mathrm{HI}$ tests with raccoon dog parvovirus, CPV and MEV and positive sera from the same species plus sera from blue foxes (Table 2). Blue fox antibodies reacted with the highest titres against FPV, and less wih raccoon dog virus or CPV.

Several farms housed more than one species of fur animal. On 4 farms, with both foxes and raccoon dogs, only the latter were diseased. 3 farms had serologically positive foxes, the raccoon dogs being negative.

The blue fox parvovirus has spread rapidly to western and southern Finland during the investigation period. In 1983, 59 farms out of a total of 169 were positive. In 1984, 142 farms were examined and 54 were found to be infected. 
Table 2. Haemagglutination inhibition titres using raccoon dog, dog and panleukopenia parvoviruses as antigens.

\begin{tabular}{lcccc}
\hline Sera from & & $\begin{array}{c}\text { Raccoon dog } \\
\text { virus }\end{array}$ & Dog parvovirus & $\begin{array}{c}\text { Panleukopenia } \\
\text { virus }\end{array}$ \\
\hline \multirow{2}{*}{ Raccoon dogs } & 1 & 1280 & 640 & $320-640$ \\
& 2 & 2560 & $1280-2560$ & $1280-2560$ \\
Dogs & 3 & 1280 & 640 & $320-640$ \\
& 1 & 640 & 1280 & 320 \\
Cats & 2 & 1280 & 2560 & 1280 \\
& 3 & 1280 & 2560 & 1280 \\
Blue foxes & 1 & 2560 & 2560 & 5120 \\
& 2 & 320 & $160-320$ & 1280 \\
& 3 & 80 & 40 & 160 \\
& 2 & 640 & $640-1280$ & 1280 \\
& 3 & 640 & 640 & 1280 \\
& 3 & 320 & 320 & 640 \\
\hline
\end{tabular}

Mink

When testing was done with the HI 26 mink out of a total of 942 appeared to give a positive parvovirus reaction (Table 1 ). The positive reactors were found on 5 farms out of 20 tested. The results indicated that the $H I$ test could not detect vaccination titres and the values in Table 1 represented samples from infected animals. Following this finding the ELISA test was used to evaluate the response to vaccination (Table 3 ). There

T a b l e 3. Mink sera tested by the ELISA method.

\begin{tabular}{rrc}
\hline Farm No. & $\begin{array}{c}\text { Positive } \\
\text { mink/tested }\end{array}$ & $\begin{array}{c}\text { MEV-infected } \\
\text { mink with high } \\
\text { titres }\end{array}$ \\
\hline 1 & $3 / 20$ & - \\
2 & $6 / 20$ & 2 \\
3 & $11 / 20$ & - \\
4 & $3 / 20$ & - \\
5 & $16 / 20$ & - \\
6 & $8 / 17$ & - \\
7 & $9 / 20$ & - \\
8 & $0 / 20$ & - \\
9 & $9 / 18$ & 15 \\
10 & $23 / 23$ & - \\
11 & $17 / 22$ & - \\
13 & $17 / 23$ & - \\
\hline
\end{tabular}


was great variation between farms as regarded the proportion of positive mink. One farm was totally negative and one had an outbreak of mink enteritis, all the animals being positive.

\section{DISCUSSION}

This investigation indicates that the ferret cannot be a host to a field infection by a parvovirus related to FPV or MEV. The negative findings correlate well with the earlier reports by Ryland \& Gorham (1978) and Neuvonen et al. (1982). In experimental infections only neonatal animals inoculated intracerebrally with FPV or MEV were susceptible and showed ataxia. The other symptoms of feline panleukopenia could not be induced in the classical forms as observed in their natural host, i.e. cats and mink.

During the 4 years which have passed since parvoviral diarrhoea was first discovered in raccoon dogs, the disease has spread gradually all over the country. The disease reached the western coast in 1985. The infection has been transmitted primarily by breeding animals. The fact that adults can act as symptomless virus carriers (Neuvonen et al. 1982) has made the situation worse. A few outbreaks may be due to the transmission of CPV from domestic dogs, nevetheless, fur farmers are aware that dogs or cats should not be allowed to come into close contact with caged animals. In nature such infectional pathways are common. Since the virus was discovered in Finland in 1979 we have isolated CPV from feral raccoon dogs living in urban areas.

During the primary outbreak in eastern Finland the mortality rate among kits varied from 3 to $30 \%$ (Neuvonen et al. 1982). Recently rates of as high as $50 \%$ have occurred on newly infected farms in West Finland. Circumstantial factors such as the mode of infection, possible presence of other infectious agents and unsuitable weather conditions can strengthen the pathogenicity of the infection.

Raccoon dog parvovirus replicates well in many canine and feline cell lines propiolactone inactivated homologous vaccine has been used for inoculating 8 weeks old kits in order to eradicate the disease. Unfortunately the situation on farms is similar to parvo contaminated kennels where high maternal antibodies interfere and prevent the development of a sufficient immune response (Pollock et al. 1982). Vaccination diminishes losses, but does not totally prevent the clinical disease. 
Blue fox parvovirus is a possible new member to the group of enteric parvoviruses. The only information available about a similar condition is in a report on arctic for which suffered from a disease that clinically and pahologically resembles feline panleukopenia (Phillips 1943). Positive anti-parvo titres in feral red foxes have been found in Canada by Barker et al. (1983), and the same workers have experimentally infected red foxes with CPV, MEV and FPV. The viruses did not cause any clinical symptoms, although a high antibody response was found to FPV inoculation.

The results from the HI test made using raccoon dog parvovirus, CPV and FPV as the HA antigen indicate that blue fox parvo may be antigenically closer related to FPV than to CPV. Furthermore, it is not the same virus which infects raccoon dogs because farms with parvo-positive raccoons have negative foxes and vice versa. The silver fox (Vulpes vulpes) also seems to be considerably resistant to blue fox virus. The deduction is based, however, on a very small test material and remains to be confirmed.

When the first blood samples were collected in 1981, the disease appeared to be a new one since only a few farms in a restricted area were contaminated. Since then the disease has spread rapidly via breeding animals and, like raccoon dog enteritis, can today be found in all parts of the country.

The clinical signs have been mild. It has not been possible to connect unusual outbreaks of enteric disease with serologic findings. However, the number of abortions and neonatal deaths seemed to increase in parallel with the novel infection.

After 20 years of extensive vaccination MEV infection has not been totally eradicated from fur farms. The clinical disease characterized by severe enteritis and the death of kits, has changed to a subclinical form which often remains unidentified. According to the results in Table 3 and the HI results not shown in detail the most common situation on farms with MEV is that 1 to 2 individual mink per 50 examined show high antibody titres. A more severe outbreak was found on farm No. 10. According to the owner, the clinical signs were poor growth and occasional, transient diarrhoea.

Table 3 does not give a precise picture of the effectiveness of vaccination because the mink tested were not selected i.e. according to their age. The samples were obtained both from breed- 
ing animals and from younger ones born in the same year. Mink are vaccinated only once at the age of 8 weeks so the negative results may represent the older mink with a diminished vaccination titer, as well as youngsters where vaccination has been unsuccesfull. The animals on farm No. 8, which was totally negative, were unvaccinated.

According to the results subclinical MEV infections are common. In order to avoid economical losses the vaccination program must be carried out annually. Sera from juvenile mink at pelting time should be collected and tested serologically in order to study the reasons for variable effects of immunisation with vaccines.

\section{AGKNOWLEDGEMENT}

This study was financially supported by the Finnish Fur Breeders Association.

The author thanks Dr. M. Eskildsen, Dr. J. C. Lei and Dr. K. Dalsgaard from Lindholm, Denmark, for advice concerning parvovirus diagnostics. The skillful assistance of Mrs. Anja Menahem and Miss Minna Haataja is greatly appreciated.

\section{REFERENCES}

Appel, H. J. G., B. J. Cooper, H. Greisen, F. Scott \& L. E. Carmichael: Canine viral enteritis. 1. Status report on corona- and parvolike viral enteritides. Cornell Vet. 1979, 62, 123-133.

Barker, I. K., R. C. Povey \& D. R. Voigt: Response of mink, skunk, red fox and raccoon to inoculation with mink enteritis, feline panleukopenia an canine parvovirus and prevalence of antibody to parvovirus in wild Carnivores in Ontario. Canad. J. comp. Med. 1983, 47, 188-197.

Carmichael, L. E., J. C. Joubert \& R. V. M. Pollock: Haemagglutination by canine parvovirus: serologic studies and diagnostic applications. Amer. J. vet. Res. 1980, 41, 784-791.

Evermann, J. F., W. Foreyt, L. Maag-Miller, C. W. Leathers, A. J. McKeirnan \& B. Lea Master: Acute hemorrhagic enteritis associated with canine coronavirus and parvovirus infections in a captive coyote population. J. Amer. vet. med. Assoc. 1980, 177, $784-786$.

Fletcher, K. C., A. K. Eugster, R. E. Schmidt \& G. B. Hubbard: Parvovirus infection in manned wolves. J. Amer. vet. med. Assoc. $1979,175,897-900$.

Frelier, P. F., R. W. Leininger, L. D. Armstrong, P. N. Nation \& R. C. Povey: Suspected parvovirus infection in porcupines. J. Amer. vet. med. Assoc. 1984, 185, 1291-1294.

Grauballe, P. C., B. F. Vestergaard, A. Meyling \& J. Genner: Optimized enzyme-linked immunosorbent assay for detection of human 
and bovine rotavirus in stools. Comparison with electron microscopy, immunoelectro osmophoresis and fluorescent antibody techniques. J. med. Virol. 1981, 7, 29-40.

Janssen, D. L., C. R. Bartz, M. Bush, R. H. Marchwicki, S. J. Grate \& R. J. Montali: Parvovirus enteritis in vaccinated juvenile bush dogs. J. Amer. vet. med. Assoc. 1982, 181, 1225-1227.

Jaton, J.-C., D. Brandt \& P. Vassalli: The isolation and characterization of immunoglobulins, antibodies and their constituent polypeptide chains. In: Immunological Methods. Academic Press, Inc., New York 1979, p. 43-67.

Johnson, L. M. \& J. R. Gorham: The ferret and its diseases. J. Amer. vet. med. Assoc. 1978, 173, 1154-1158.

Kangas, J.: Minkkien virusripulin esiintyminen Suomessa (Viral enteritis of mink in Finland). Suomen Eläinlääk Lehti 1962, 68, 261-269.

$L e i, J . C .:$ Report of the session of the research group of the standing committee of the European commission for the control of FMD. Uccle, Belgium, FAO, Rome, 1978.

Mann, P. C., M. Bush, M. J. G. Appel, B. A. Beehler \& R. J. Montali: Canine parvovirus infection in South American canids. J. Amer. vet. med. Assoc. 1980, 177, 779-783.

McMaster, G. K., J.-D. Tratschin \& G. Siegl: Comparison of canine parvovirus with mink enteritis virus by restriction site mapping. J. Virol. 1981, 38, 368-371.

Neuvonen, E., P. Veijalainen \& J. Kangas: Canine parvovirus infection in housed raccoon dogs and foxes in Finland. Vet. Rec. 1982, $110,448-449$.

Parrish, C. R., L. E. Carmichael \& D. F. Antezah: Antigenic relationship between canine parvovirus type 2 feline panleukopenia virus and mink enteritis virus using conventional antisera and monoclonal antibodies. Arch. Virol. 1982, 72, 267-278.

Phillips, C. E.: Haemorrhagic enteritis in the arctic blue fox caused by the virus of feline enteritis. Canad. J. comp. Med. 1943, 7, $33-35$.

Pollock, R. V. H. \& L. E. Carmichael: Maternally derived immunity to canine parvovirus infection: transfer, decline and interference with vaccination. J. Amer. vet. med. Assoc. 1982, 180, $37-42$.

Ryland, L. M. \& J. R. Gorham: The ferret and its diseases. J. Amer. vet. med. Assoc. 1978, 173, $1154-1158$.

Stann, S. E., R. F. Digiacomo, W. E. Giddens \& J. F. Evermann: Clinical and pathologic features of parvoviral diarrhea in pound-source dogs. J. Amer. vet. med. Assoc. 1984, 185, 651655.

The, T. H. \& T. E. W. Feltkamp: Conjugation of fluorescein isothiocyanate to antibodies II. A reproducible method. Immunology 1970, 18, 875-888. 
Thomas, N. J., W. J. Foreyt, J. F. Evermann, L. A. Windberg \& F. F. Knowlton: Seroprevalence of canine parvovirus in wild coyotes from Texas, Utah and Idaho (1972 to 1983). J. Amer. vet. med. Assoc. 1984, 185, 1283-1287.

Tratschin, J.-D., G. K. McMaster, G. Kronauer \& G. Siegl: Canine parvovirus: Relationship to wild-type and vaccine strains of feline panleukopenia virus and mink enteritis virus. J. gen. Virol. 1982, 61, 33-41.

Wilson, M. B. \& K. P. Nakane: Recent developments in the perjodate method of conjugating horseradish peroxidase (HRPO) to antibodies. In: Immunofluorescence and Related Staining Techniques (ed. W. Knapp, R. Holular and G. Wick). Elsevier/ North-Holland Biomed. Press, Amsterdam 1978, p. 215-224.

\section{SAMMANFATTNING}

Serologiska studier över parvovirusinfektioner hos finska pälsdjur.

Parvovirusinfektioner hos iller, mårdhund, blåräv och mink studerades. Av dessa visade sig illern vara den enda okänsliga djurarten. Den år 1980 rapporterade parvoenteriten hos mårdhundarna har spritt sig från östra Finland till andra delar av landet. En ny medlem i parvovirusfamiljen visade sig vara smittosam för blårävar. Serologiskt påminner viruset mera om kattpestvirus än om hundens parvovirus. Den kliniska bilden är mild.

Årligen utförda vaccinationer har inte utplånat minkenteritviruset från farmerna. Infektionen präglas av en subklinisk form.

(Received January 16, 1986).

Reprints may be requested from: Pirjo Veijalainen, the National Veterinary Institute, PO Box 368, SF-00101, Helsinki, Finland. 